\title{
SUPPLY CHAIN AND LIFE CYCLE COST OF ROOFING IN SABAH: A CASE STUDY
}

\author{
Lillian Gungat ${ }^{1 *}$, Kurian V. John ${ }^{2} \&$ Rohayah Ladom ${ }^{3}$ \\ ${ }^{1}$ Lecturer, Civil Engineering, School of Engineering \& IT, Universiti Malaysia Sabah, Sabah, Malaysia \\ ${ }^{2}$ Professor, Civil Engineering, Universiti Teknologi Petronas, Perak, Malaysia \\ ${ }^{3}$ Engineer, Cawangan Cerun, Jabatan Kerja Raya, Sabah, Malaysia \\ *lilliangungat@gmail.com or lillian@ums.edu.my
}

\begin{abstract}
The roofing industry in Sabah has undergone marked changes and improvement in its quality and performance for the past 20 years in response to changes in local environment. In recent years, an increasing number of practitioners in the roofing construction industry in Sabah have observed that information related to roofing selection in terms of suitability and cost effectiveness is limited. This paper reports the results of an investigation on the supply chain of roofing materials in Sabah. All data were obtained based on information gathered through questionnaires, site visits and interviews with number of practitioners working in related fields such as developers, engineers, contractors, roofing manufacturers, suppliers, government agencies and occupiers. Recommendations to rectify the identified weaknesses along the supply chain have been suggested. Besides that, comparative life cycle cost analysis was carried out based on source of roofing, maintenance planning and installation alternative. Life cycle cost comparison study proved that the roofing system obtained through distributor agents gave the lowest total life cycle cost (TLCC) and highest net saving, while, roofing system obtained through stockists gave the highest TLCC and lowest net saving. Proper maintenance planning and quality of roofing system were identified as the main factors that influenced the life cycle cost value.
\end{abstract}

Keywords: Roofing Selection, Supply Chain, Source of Roofing, Life Cycle Cost \& Maintenance Planning.

\section{Introduction}

As part of the building envelope, roofing system is primarily an assemblage of interacting components to protect the building interior, its contents and occupants from weather or any dangerous influence from the outside surroundings. Even though roofing system is only a minor component in a building, neglecting roofing system of any kind can cause its failure which will often result in extensive damage to the building and legal claims against architects, contractors and manufacturers. Therefore, for minimizing these problems, roofing designers, contractors, building owners and clients must be aware of the requirements for a good roof. Selection and design of a proper roofing system require information about the design parameters of the building itself such as aesthetic consideration, local environmental demand, roofing structural design, installation etc. (Laaly, 1992). Seeley (1980) pointed out several factors influencing the choice of roofing type namely size and shape of the buildings, appearance, economics and ease of installation and maintenance. Satisfactory performance of roof could be ensured through the coordinated efforts of everyone participating in the design and construction, together with adherence to the design standards, product usage and application. Therefore, understanding the supply chain of roofing materials is important for the manufacturing, procurement and installation of the roofing system. Supply chain is described as a series of linked activities that the materials undergo wherein a number of business entities such as suppliers, manufacturers, distributors and retailers work together in an effort to convert 
the raw materials to a product and deliver it to customers (Beamon, 1998). For the case of metal roof, there are four main parties involves in the roofing supply chain namely; supplier of metal coil, coatings and pre-treatment chemicals, coil coaters, roll formers and contractors ( Oliver et al., 1997). Supply chain is increasingly becoming an important criterion in logistic management of roofing materials for companies involved in various types of housing and building projects.

The selection of roofing system for a building is one of the important decisions that an architect or a client makes in a project. In some cases, the client would prefer a system with the lowest initial capital cost due to budgetary constraints (Hassanain et. al, 1999). Most often, lowest initial cost leads to selection of materials with low quality and often without any definite identity (Oliver et al., 1997). Lowest initial cost also may produce short-term cost saving. However, short-term cost savings which lead to high future cost would be clearly established as a result of the life cycle cost analysis. The use of life cycle cost analysis to support decision making process raises the awareness of owners, clients and the public of the total cost of projects and thus promotes quality and comprehensive engineering solutions (ASCE, 2009). Carruba(1992) promotes the use of life cycle cost physical model as a means to close the gap between a manufacturer perspective and consumer perspective. Lack of overviews of the whole elements in a building project, means that the client is not educated about the benefits of life cycle cost analysis (Whyte, 2001). Nowadays, due to increasing competition, increasing cost of ownership, rising inflation, expensive products and increasing awareness among product users, the use of life cycle cost concept has increased in the industrial and construction sectors. It is recommended that the life cycle cost planning be conducted at the design stage of a house, as huge savings could be made later (Tapsir et al, 2001). The usefulness of a life cycle cost analysis lies not in the determination of the total cost of a project, but in the ability to compare the costs of project alternatives and to determine which alternative provides the best value per dollar spent (Mearing et al, 1999).

For the past 20 years, the roofing industry in Sabah had undergone marked changes and improvements in its quality and performance. This was in response to changes in local environment such as the increase of competitors in the industry and the increase of quality and price to meet the customers' requirements. A wide range of roofing system products is available in Sabah providing the customers with considerable choice. Among all types of roofs, metal roofing systems have been used for long time and most commonly whereby about $80-90 \%$ of residential and non residential buildings used metal roofs (Rohayah, 2005). A total of 5 out of 7 manufacturers, located in Kota Kinabalu, the Capital City of Sabah, produce metal roofs.

In recent years, an increasing number of practitioners in the roofing construction industry have observed that information related to roofing selection is limited especially in Sabah. Though the problem had been recognized, there was still no means yet to improve the process in order to assist the client and customer towards the selection of suitable and cost effective roofing system in the supply chain. This paper presents the results of case studies based on qualitative investigation of roofing material supply chain in Sabah. Life cycle cost analysis with emphasize on source of roofing, maintenance planning and installation alternative was carried out to prepare roofing selection guideline for clients. Based on this study, Universiti Malaysia Sabah \& CIDB have published guidelines for the supply chain of metal roofs in Sabah (UMS \& CIDB, 2005). 


\section{Materials and Methods}

This study involved qualitative investigation using questionnaire survey, interview and site visit. Preliminary visits to roofing manufacturers, suppliers, distributors, contractors, architects, developers and government agencies were made prior to the questionnaire design. The preliminary visits were supplemented with interviews, workshops, informal meetings and email communications. The questionnaire addressed the type of substrate used, warranty, design guidance, roofing worker expertise, roofing maintenance and management, cost of roofing installation and maintenance, periodicity of roofing maintenance and replacement, problems related to roofing service performance and installation and safety at site. The questionaires were distributed to manufacturers, suppliers, contractors, developers and occupiers via post and interview. At the same time, selected houses and school projects built by main contractors from Grade 3 to Grade 7 (based on CIDB classification) were visited in order to conduct in-depth interviews with clients. The major roofing manufacturing plants and suppliers in Sabah were visited and interviews conducted. The occupiers for different types of low cost and medium cost terrace houses, commonly built in Sabah, were interviewed to get input on roofing maintenance and management. The gathered data were then compiled and analyzed using a standard software SPSS. For the Life Cycle Cost (LCC) analysis, CADAFIS software was used. All input for the LCC analysis were based on the standard and compiled information from the questionnaire, site visits and interviews. Three main criteria were used for LCC analysis namely: source of roofing materials, system maintenance planning and roof system component and installation alternative. Figure 1 illustrates the flowchart of methodology in this study.

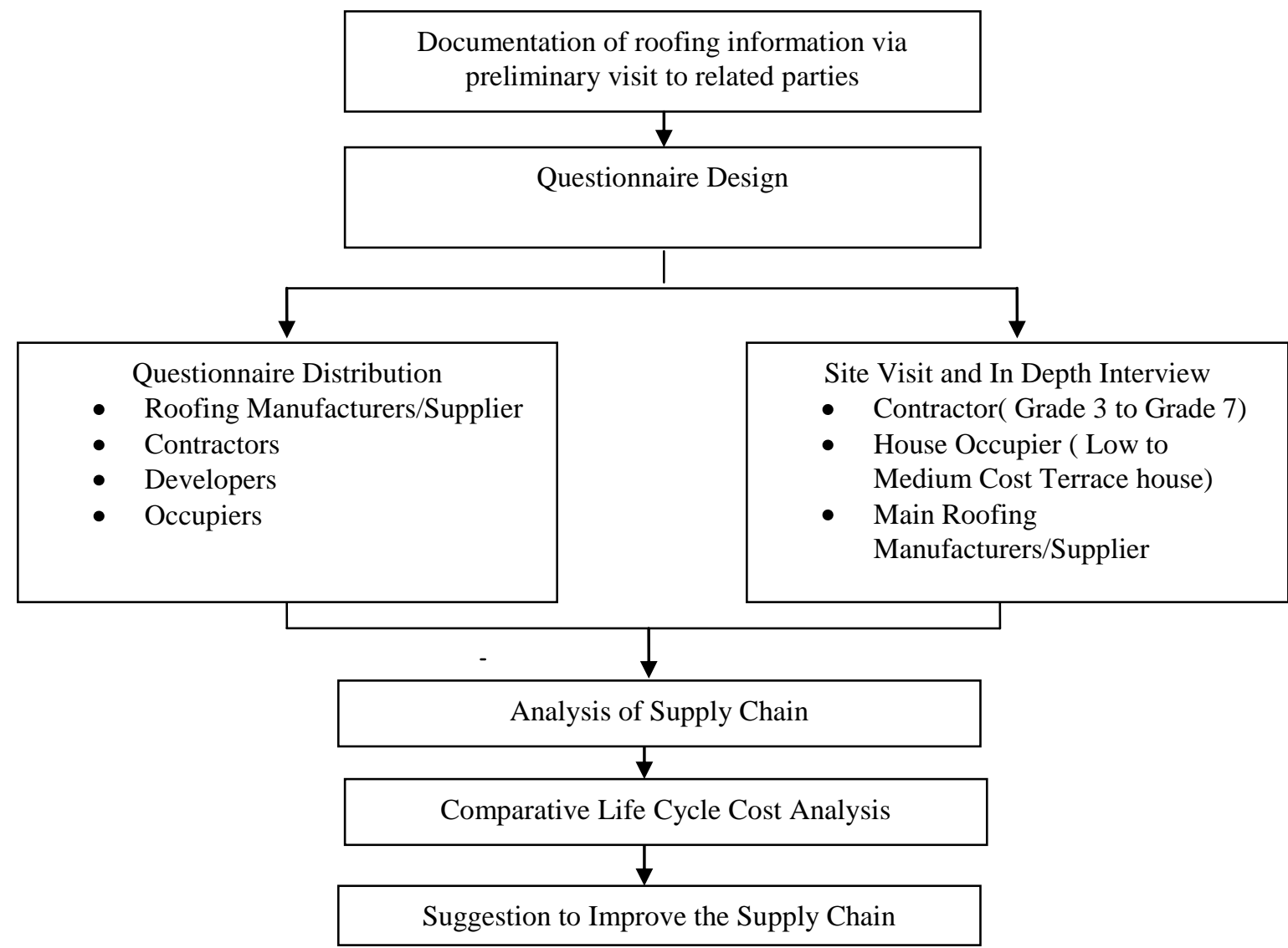

Figure 1: Flowchart of Methodology 


\section{Results and Discussion}

\subsection{Supply Chain of Roofing Material}

The current practice of roof system supply chain, that was studied, illustrates the activities involved from materials procurement, individual functions and installation on site. The questionnaires were distributed among 449 organizations and a total of $32 \%$ replied. The reason for lack of response may be due to unrelated nature of business or wrong address. As an alternative, interviews with selected parties directly involved in roofing business were carried out. From the analysis, there are two major findings which are; how clients choose the roofing system and supply chain of roofing material in Sabah. In roofing material selection there were several identified parties involved namely client/building owner, manufacturer/supplier, main contractor and roof worker. Normally, the client has the freedom for specifying the roofing system and appoints main contractor and manufacturer. The manufacturer is in charge of detailing, designing and fabricating the roofing system while the main contractor is in charge of recruiting roofing workers. The current practice in roof system selection in Sabah is shown in Figure 2.

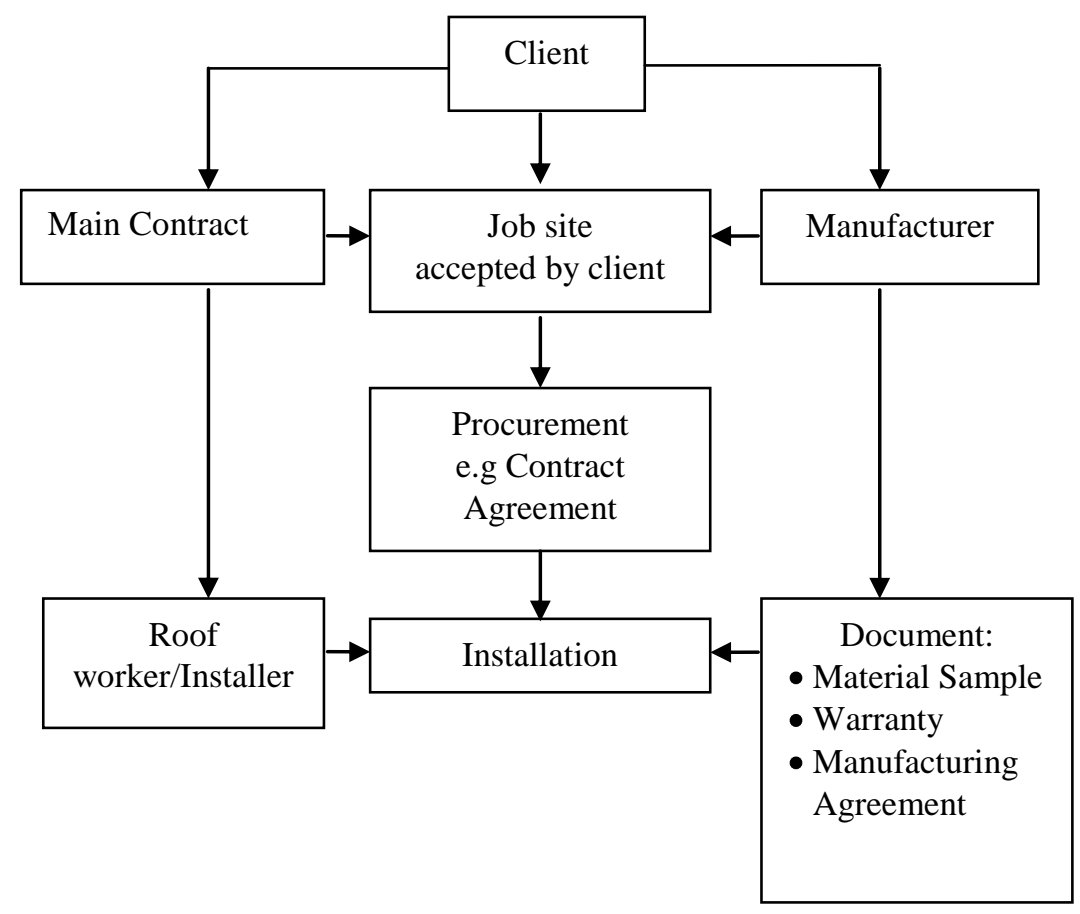

Figure 2: Current Practice in Roof System Selection in Sabah

Currently, the roofing materials at Sabah normally reach users through three different ways namely: stockist, distributer agent appointed by manufacturer and roll former. The current supply chain of roofing materials is shown in Figure 3. A user has the freedom to obtain the roofing materials regardless of the roofing 
type. However, location could also be one of the user constraints in obtaining the roofing materials through the three mentioned methods. For instance in rural area, roofing materials can only be obtained through stockists.

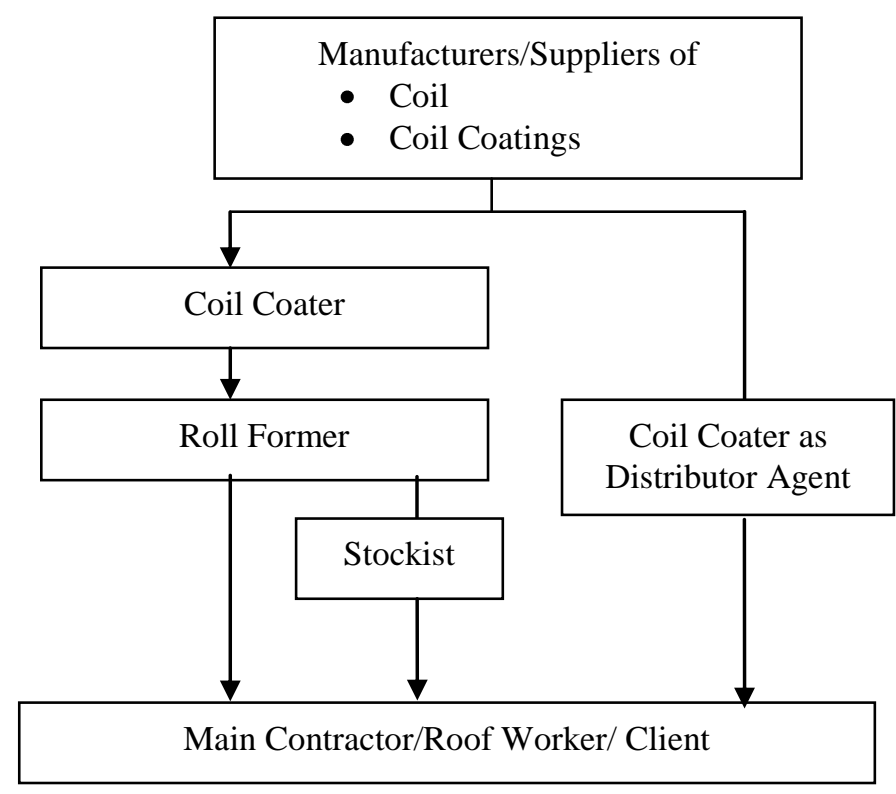

Figure 3: Supply Chain of Roofing Materials in Sabah

Based on the current supply chain and findings from the interview, potential weaknesses along the flowchart were identified. These were:

- As there was no standardization of coil coating, there was the possibility of using less durable coatings, thus causing corrosion.

- Design of attractive roof profiles produced by roll former to attract the client caused problem during the installation, if done by untrained workers.

- The rates quoted by various stockists differed widely even up to very high costs. The clients also faced difficulty in getting the technical assistance if purchased through stockists.

- Installation problems such as poor workmanship, insufficient skilled labor and non-adherence to the supplier's specification during construction indirectly affected the roofing performance in the long run.

\subsection{Life Cycle Cost Analysis}

Basically, life cycle cost analysis involves four basic cost elements associated with roofing system of any buildings. These cost elements are initial, maintenance and repair, replacement and salvage. In this study, criteria for Life Cycle Cost (LCC) analysis were based on feedbacks from interview, questionnaire and site visit. Based on collected data and information received from manufacturers and suppliers, the main cost differences are due to material prices. Therefore the LCC analysis focused on the cost of materials and installation. Type of house selected was low cost terrace house with roof area and slope approximately $47 \mathrm{~m}^{2}$ and $30^{0}$ respectively. The study was carried out for a life cycle period of 30 years with discount rate of $3.7 \%$. The estimated service 
life for each roofing scenario was adjusted based on the experience of the clients and house owners, as well as based on the data obtained from manufacturers and suppliers. The criteria that were considered for LCC analysis is tabulated in Table 1.

Table 1: Roofing Criteria for LCC analysis.

\begin{tabular}{|c|c|}
\hline Criteria & Description \\
\hline $\begin{array}{l}\text { Source of roofing } \\
\text { materials }\end{array}$ & $\begin{array}{ll}\text { - } & \text { Stockist (Roof 1) } \\
\text { - } & \text { Distributor Agent (Roof 2) } \\
\text { - } & \text { Roll Former (Roof 3) }\end{array}$ \\
\hline $\begin{array}{l}\text { Roof system maintenance } \\
\text { planning }\end{array}$ & $\begin{array}{l}\text { - Replacement Management } \\
\text { - Schedules Maintenance }\end{array}$ \\
\hline $\begin{array}{l}\text { Roof system components } \\
\text { and installation } \\
\text { alternative }\end{array}$ & $\begin{array}{l}\text { - Conventional roof systems with aluminium foil insulation installed above } \\
\text { rafter. } \\
\text { - Conventional roof system that has fiberglass insulation with different } \\
\text { thickness of } 25 \mathrm{~mm} \text { and } 50 \mathrm{~mm} \text { sandwiched between the roofing membrane } \\
\text { and the rafter. } \\
\text { - Conventional roof system that has both aluminium foil and fiberglass with } \\
\text { thickness of } 25 \mathrm{~mm} \text { and } 50 \mathrm{~mm} \text { sandwiched between the roofing membrane } \\
\text { and the rafter. } \\
\text { - Lay in insulated ceiling that has roofing over an uninsulated rafter. The } \\
\text { ceiling is insulated with thickness of } 25 \mathrm{~mm} \text { and } 50 \mathrm{~mm} \text { of fiberglass } \\
\text { insulation laid across the ceiling. }\end{array}$ \\
\hline
\end{tabular}

The comparison of results of total life cycle cost (TLCC) of roof system based on the current and alternative practices are summarized in Table 2 and Table 3 respectively. Referring to the results in Table 2, the roof materials obtained through distributor agent provides the lowest TLCC ranging from RM 4,182 to RM 4,433 and highest net saving ranging from RM 2,061 to RM 2,152 per unit house for 30 year study period. Roofing materials obtained from stockist (Roof 1) gives highest TLCC and lowest net saving. Similar trend was observed in Table 3 with maintenance management. Stockist normally mark-up price of roofing materials supplied by manufacturer and this explains the highest TLCC and lowest net saving of materials obtained from stockist. From Tables 2 and 3, it can be observed that the TLCC of roof systems with lay-in insulated ceiling are lower than the TLCC of conventional roof systems. The result shows that it is more economical to position the insulation across the ceiling rather than in the plane of the rafters for pitched roof. Nevertheless, the thickness of fiberglass for ceiling insulation increased the TLCC for all roof systems. 
Table 2: Comparison Study of TLCC and Net Saving for Different Roof Systems with Replacement Management.

\begin{tabular}{|c|c|c|c|}
\hline Insulation Type & Roof system & $\begin{array}{l}\text { TLCC } \\
\text { (RM) }\end{array}$ & Total Net Saving (RM) \\
\hline \multirow{3}{*}{$\begin{array}{l}\text { Conventional } \\
\text { (Aluminum Foil) }\end{array}$} & 1 & 6,243 & - \\
\hline & 2 & 4,182 & 2,061 \\
\hline & 3 & 5,304 & 939 \\
\hline \multirow{3}{*}{$\begin{array}{l}\text { Conventional } \\
\text { (Fiberglass } 25 \mathrm{~mm} \text { ) }\end{array}$} & 1 & 6,419 & - \\
\hline & 2 & 4,311 & 2,108 \\
\hline & 3 & 5,475 & 944 \\
\hline \multirow{3}{*}{$\begin{array}{l}\text { Conventional } \\
\text { (Fiberglass } 50 \mathrm{~mm} \text { ) }\end{array}$} & 1 & 6,494 & - \\
\hline & 2 & 4,366 & 2,128 \\
\hline & 3 & 5,547 & 947 \\
\hline \multirow{3}{*}{$\begin{array}{l}\text { Conventional } \\
\text { (Aluminum Foil and Fiberglass } 25 \\
\mathrm{~mm} \text { ) }\end{array}$} & 1 & 6,510 & - \\
\hline & 2 & 4,378 & 2,132 \\
\hline & 3 & 5,563 & 947 \\
\hline \multirow{3}{*}{$\begin{array}{l}\text { Conventional } \\
\text { (Aluminum Foil and Fiberglass } 50 \\
\mathrm{~mm} \text { ) }\end{array}$} & 1 & 6,585 & - \\
\hline & 2 & 4,433 & 2,152 \\
\hline & 3 & 5,636 & 949 \\
\hline \multirow{3}{*}{$\begin{array}{l}\text { Insulated } \\
\text { (lay in insulated ceiling with } \\
\text { fiberglass } 25 \mathrm{~mm} \text { ) }\end{array}$} & 1 & 6,243 & - \\
\hline & 2 & 4,182 & 2,067 \\
\hline & 3 & 5,304 & 939 \\
\hline \multirow{3}{*}{$\begin{array}{l}\text { Insulated } \\
\text { (lay in insulated ceiling with } \\
\text { fiberglass } 50 \mathrm{~mm}\end{array}$} & 1 & 6,276 & - \\
\hline & 2 & 4,200 & 2,061 \\
\hline & 3 & 5,327 & 940 \\
\hline
\end{tabular}

Note: Stockist (Roof 1), Distributor Agent (Roof 2) and Roll Former (Roof 3) 
Table 3: Comparison Study of TLCC and Net Saving for Different Roof Systems with Maintenance Management.

\begin{tabular}{|c|c|c|c|}
\hline Insulation Type & Roof system & TLCC (RM) & $\begin{array}{l}\text { Total Net Saving } \\
(\mathrm{RM})\end{array}$ \\
\hline \multirow[t]{3}{*}{ Conventional ( Aluminum Foil) } & 1 & 4,672 & 1,571 \\
\hline & 2 & 3,714 & 2,529 \\
\hline & 3 & 4,407 & 1,836 \\
\hline \multirow{3}{*}{$\begin{array}{l}\text { Conventional } \\
\text { ( Fiberglass 25mm) }\end{array}$} & 1 & 4,759 & 1,660 \\
\hline & 2 & 3,801 & 2,618 \\
\hline & 3 & 4,494 & 1,925 \\
\hline \multirow{3}{*}{$\begin{array}{l}\text { Conventional } \\
\text { ( Fiberglass 50mm) }\end{array}$} & 1 & 4,796 & 1,698 \\
\hline & 2 & 3,838 & 2,656 \\
\hline & 3 & 4,531 & 1,963 \\
\hline \multirow{3}{*}{$\begin{array}{l}\text { Conventional } \\
\text { (Aluminum Foil and Fiberglass } \\
25 \mathrm{~mm} \text { ) }\end{array}$} & 1 & 4,804 & 1,706 \\
\hline & 2 & 3,846 & 2,664 \\
\hline & 3 & 4,539 & 1,971 \\
\hline \multirow{3}{*}{$\begin{array}{l}\text { Conventional } \\
\text { (Aluminum Foil and Fiberglass } \\
50 \mathrm{~mm})\end{array}$} & 1 & 4,841 & 1,744 \\
\hline & 2 & 3,883 & 2,702 \\
\hline & 3 & 4,576 & 2,009 \\
\hline \multirow{3}{*}{$\begin{array}{l}\text { Insulated } \\
\text { (lay in insulated ceiling with } \\
\text { fiberglass } 25 \mathrm{~mm} \text { ) }\end{array}$} & 1 & 4,672 & 1,571 \\
\hline & 2 & 3,714 & 2,529 \\
\hline & 3 & 4,407 & 1,836 \\
\hline \multirow{3}{*}{$\begin{array}{l}\text { Insulated } \\
\text { (lay in insulated ceiling with } \\
\text { fiberglass } 50 \mathrm{~mm}\end{array}$} & 1 & 4,684 & 1,583 \\
\hline & 2 & 3,726 & 2,541 \\
\hline & 3 & 4,419 & 1,848 \\
\hline
\end{tabular}

Note: Stockist (Roof 1), Distributor Agent (Roof 2) and Roll Former (Roof 3)

In terms of maintenance program, it was observed that roof systems with maintenance management provided higher cost savings compared with roof systems with replacement management. The TLCC results indicated that the maintenance program influenced the TLCC and net saving values. The findings also indicated that for metal roof systems, recoating a corroded or badly weathered roof can be an economical alternative compared with total replacement. Apart from that, the life expectancy of the roofing investment can be maximized through a scheduled maintenance management. Therefore, the maintenance program recommended by the manufacturer for metal roof system should be practiced (Scharff \& Kennedy, 2000). 
In general, the longer the service life, the more expensive is the material. Nevertheless, this material will be economical in the long run because the cost of material and labor is amortized over a long period of time. It should also be noted that the actual roof performance depends on several important aspects such as quality, maintenance, installation procedure and environment. Thus all the criteria should be carefully considered when selecting an affordable good quality roof system.

\subsection{Recommended Roof System Selection Process}

This study clearly shows that selection of the appropriate type of roof for specific building based on the client's preference is very important. Findings from the comparative analysis of life cycle cost indicated that source of roofing materials, type of installation and material as well as maintenance program influenced the TLCC value. With reference to the roofing system selection in Sabah, there are no specific roofing selection guidelines available at present. Architects and engineers only choose and design what they consider the best solution based on the client's primary concern on the project requirements and cost constraints. In order to make the optimal selection, costs and benefits of many available system options could be carried out. Therefore, it is recommended that life cycle cost analysis to be included in the roofing selection process. Figure 3 shows the recommended method to improve the selection of roofing in the supply chain.

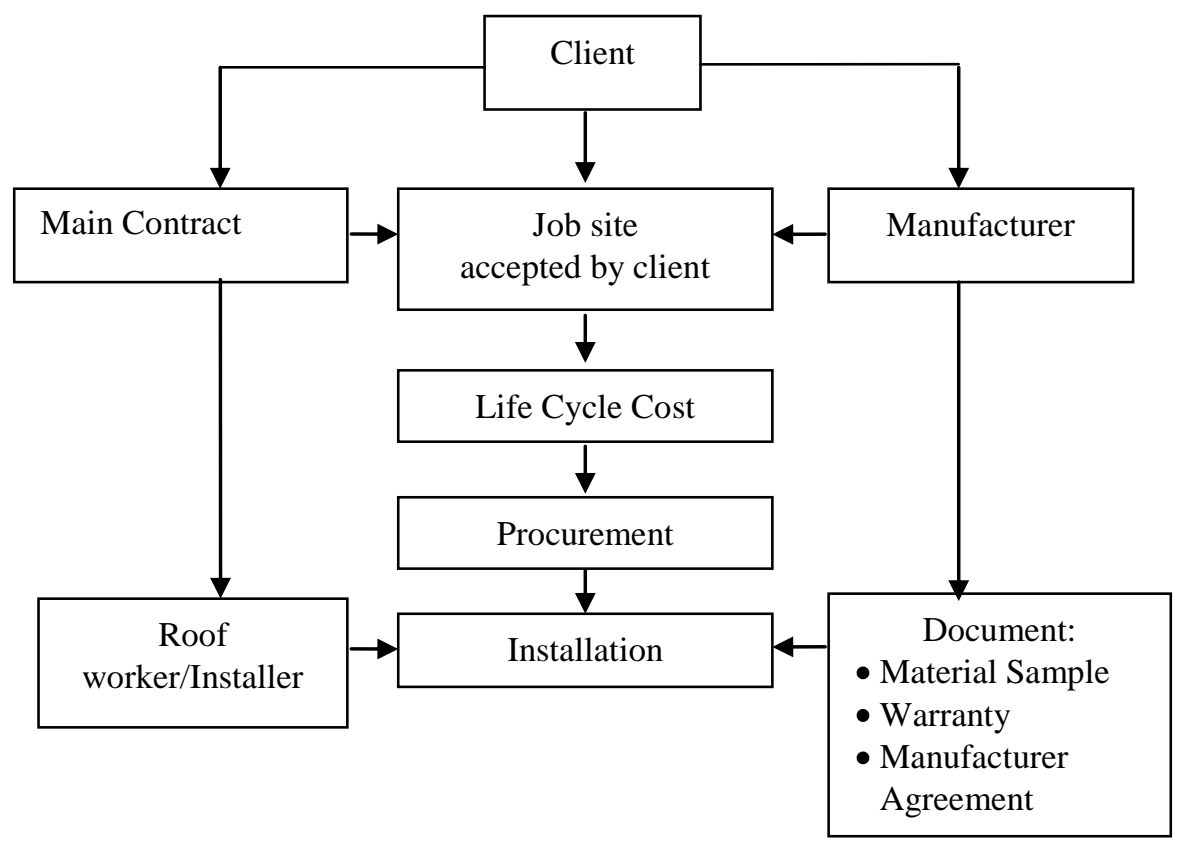

Figure 3 : Recommended Method for Roof System Selection Process

\section{Conclusion}

From this study, the following conclusions were drawn:

- Weak procedures in the supply chain show the possible routes for materials with low durability and profiles to reach the market. This influences the overall performance of the roofing. 
- Roofing manufacturer involvement in early design and construction process is encouraged to minimize the problems related to roofing.

- Source of roofing materials and initial capital requirement influenced the TLCC value. The initial capital requirement for roofing system through distributer agent is higher, but gives the lowest TLCC. Therefore, initial cost should not be taken as an indicator of the TLCC and net saving.

- Comparison study of TLCC and net saving for different roof systems with different maintenance program will allow user to compare various choices for roofing materials. However, regular and periodic inspection and maintenance are needed to maximize the life expectancy of these materials.

- Lack of guidelines for roofing system selection and material choice, contribute to the misunderstanding in decision making process. Therefore the recommended roofing selection process with life cycle cost analysis aims to ease the decision making process. Life cycle cost analysis as an important tool to assist clients and building owners to forecast investment over the roofing system's life period and this has been practiced in other countries.

\section{Acknowledgement}

Authors would like to acknowledge CIDB Malaysia for funding the project and to UMS for providing research facilities.

\section{References}

American Society of Civil Engineers (ASCE). (2009). ASCE Policies and Priorities - 2009 to 2010: Life Cycle Cost Analysis(PS 45)1 pp16

Beamon, B.M.(1998). Supply Chain Design and Analysis: Models and Methods. International Journal of Production Economics, 55: pp 281-294

Carubba, E. (1992). Integrating Life Cycle Cost and Cost f Ownership in the Commercial Sector. Proceedings of the Annual Reliability and Maintainability Symposium, IEE, 1992: 101-108

Hassanain M.A., Froese, T.M. \& Vanier, D. J. (1999). Information Analysis for Roofing System Maintenance Management Integrated System, National Research Council Canada, Ottawa

Laaly, H. O. (1992). The Science and Technology of Traditional and Modern Roofing Systems. Laaly Scientific Publishing, Los Angeles

Mearing,T., Coffee, N. \& Morgan, M. 1999. Life Cycle Cost Analysis Handbook, $1^{\text {st }}$ Edition. Alaska Department of Education \& Early Development. Alaska

Oliver, M.S., Albon, J.M. \& Garner, N.K. (1997). Coated Metal Roofing \& Cladding. London: Thomas Telford Rohayah N. Ladom. (2005). Roofing Specification in Sabah: Assessment of Supply Chain and Life Cycle Cost. Master Degree Thesis, Universiti Malaysia Sabah

Scharff, R. \& Kenneddy, T. (2000). Roofing Handbook. $2^{\text {nd }}$ Edition. New York. McGraw-Hill

Seeley, I. H. (1980) Building Technology. $2^{\text {nd }}$ Edition. Macmillan Press Ltd, London 
Tapsir S.H. Md Zin D.A., Ramli Z. \& Mohd Rizal A. (2001). Life Cycle Costing for Affordable Housing. International Conference on Construction Technology(CONTEC), Sabah, 2001: 213-220

UMS \& CIDB (2005). Guidelines on Thermal, Roof Drainage and Supply Chain of Metal Roofs in Sabah. UMS/CIDB 02-002. Pp 49-83

Whyte,A. (2001). Developing a Life Cycle Costing Tool to Support Muti-Disciplinary Construction Design. International Conference on Construction Technology(CONTEC), Sabah, 2001: 221-233 